\title{
Analisis Wacana Kritis pada Berita Pemilihan Walikota Makassar Sebagai Bentuk Pendidikan Politik dan Perannya dalam Pembelajaran Membaca Kritis bagi Siswa
}

\author{
Wahyuni*, Akmal Hamsa, Ramly \\ Program Pascasarjana, Universitas Negeri Makassar \\ *Corresponding Author. Email: wahyuni.uni99@gmail.com
}

\begin{abstract}
This study aims to analyze the language features in the news of the 2020 Makassar Mayor election as a form of political education and its role in critical reading learning for students. The research method used is descriptive method with a qualitative approach. Data collection techniques using documentation, reading, and recording. The data analysis technique used is Norman Fairclough's critical discourse analysis model through procedures for identifying data, classifying data, analyzing data, and drawing conclusions. The results of the study show that the language of power as a tool of power through linguistic features and has been used optimally by those who have the intention to power. This can be seen in the efforts to depict the image of the candidate pair, the delivery of the vision and program, as well as campaign activities and visits by the candidates. Through this identification, it appears that each candidate pair exercises its power in presenting the text to the reader. Through this critical discourse analysis of news, it can improve students' critical reading skills in responding to various texts in the mass media as a form of political education.
\end{abstract}

\begin{abstract}
Abstrak: Penelitian ini bertujuan untuk menganalisis fitur bahasa dalam pemberitaan pemilihan Walikota Makassar tahun 2020 sebagai bentuk pendidikan politik dan perannya dalam pembelajaran membaca kritis bagi siswa. Metode penelitian yang digunakan yaitu metode deskriptif dengan pendekatan kualitatif. Teknik pengumpulan data menggunakan dokumentasi, baca, dan pencatatan. Teknik analisis data yang digunakan yaitu model analisis wacana kritis Norman Fairclough melalui prosedur mengidentifikasi data, mengklasifikasi data, menganalisis data, dan menarik kesimpulan. Hasil penelitian menunjukkan bahasa kekuasaan sebagai peranti kekuasaan melalui fitur linguistik dan berhasil dimanfaatkan secara optimal oleh mereka yang memiliki niat berkuasa. Hal tersebut tampak dalam upaya penggambaran citra pasangan calon, penyampaian visi dan program, serta aktivitas kampanye dan kunjungan para calon. Melalui identifikasi tersebut, tampak bahwa masing-masing paslon melakukan praktik kekuasaannya dalam menyajikan teks ke pembaca. Melalui analisis wacana kritis berita ini, dapat meningkatkan kemampuan membaca kritis siswa dalam menyikapi berbagai teks-teks yang ada di media massa sebagai bentuk pendidikan politik.
\end{abstract}

\section{Article History}

Received: 05-08-2021

Revised: $18-10-2021$

Accepted: 06-11-2021

Published: 11-12-2021

\section{Key Words:}

Critical Discourse,

Political Education,

Learning,

Critical Reading.

\section{Sejarah Artikel}

Diterima: 05-08-2021

Direvisi: 18-10-2021

Disetujui: 06-11-2021

Diterbitkan: 11-12-2021

\author{
Kata Kunci: \\ Wacana Kritis, \\ Pendidikan Politik, \\ Pembelajaran, \\ Membaca Kritis
}

How to Cite: Wahyuni, W., Hamsa, A., \& Ramly, R. (2021). Analisis Wacana Kritis pada Berita Pemilihan Walikota Makassar Sebagai Bentuk Pendidikan Politik dan Perannya dalam Pembelajaran Membaca Kritis bagi Siswa. Jurnal Kependidikan: Jurnal Hasil Penelitian dan Kajian Kepustakaan di Bidang Pendidikan, Pengajaran dan Pembelajaran, 7(4), 1014-1027. doi:https://doi.org/10.33394/jk.v7i4.4108

d.

https://doi.org/10.33394/jk.v7i4.4108

This is an open-access article under the CC-BY-SA License.

\section{Pendahuluan}

Membaca kritis merupakan proses membaca yang dilakukan untuk memahami secara mendalam informasi yang terkandung dalam bacaan, baik yang tersurat maupun yang tersirat. Ahuja dan Ahuja (2010) mengemukakan bahwa membaca kritis adalah penerapan proses berpikir kritis terhadap bacaan. Melalui aktivitas membaca kritis, pembaca dapat memperoleh 
pengetahuan yang kelak dapat digunakan untuk meningkatkan kapasitas berpikirnya. Proses membaca kritis melibatkan aktivitas memahami, menginterpretasi, dan menilai informasi serta memberikan respons, terhadap beragam bacaan (Restuningsih, Dantes dan Sudiana, 2017). Beragam aktivitas membaca tersebut melibatkan proses berpikir (Priyatni dan Nurhadi, 2017). Agar maksud dan makna yang diperoleh dari membaca tidak salah penafsiran.

Keterampilan membaca kritis merupakan salah satu keterampilan membaca yang sangat dibutuhkan dewasa ini. Teknologi informasi dan komunikasi yang berkembang semakin cepat berimplikasi terhadap ketersediaan sumber-sumber dan bahan bacaan yang variatif. Beragam informasi tersedia dengan mudah yang dapat diperoleh dari berbagai media. Namun demikian, bacaan-bacaan tersebut tidak semua relevan dengan kebutuhan pembaca (Sultan, 2018). Para pembaca harus mampu memilah dan memilih serta menganalisis dan menilai informasi yang disajikan sebelum memanfaatkannya, utamanya kalangan pelajar. Dengan membaca kritis siswa harus mampu memahami secara mendalam dan menganalisa bacaan sebagai kebutuhan untuk menguji apakah informasi tersebut otentik atau tidak. Dalam pembelajaran membaca kritis di sekolah, siswa tidak hanya dituntut untuk memahami isi bacaan, tetapi juga dituntut untuk dapat memahami, menganalisis, menyimpulkan, dan menilai isi bacaan agar pemahaman siswa terhadap suatu bacaan optimal (Restuningsih, Dantes dan Sudiana, 2017).

Beragam bahan bacaan yang beredar dengan beragam media disajikan dengan tujuantujuan tertentu, tidak hanya semata-mata memberikan informasi. Bahan bacaan yang disajikan itu memiliki beragam tujuan, seperti memengaruhi pandangan, membujuk, atau menanamkan keyakinan/ideologi tertentu (Tarigan, 2008). Setiap teks dikonstruksi dan diproduksi dengan cara pandang tertentu (Fairclough, 1989 dan 1992). Penulis teks biasanya menjadikan kegiatan literasi sebagai sasaran untuk mempengaruhi opini pembaca (Cervetti, Pardales, dan Damico; 2001). Dengan tersebarnya berbagai macam teks yang berisikan informasi yang belum tentu benar dan baik untuk dikonsumsi, haruslah dibarengi dengan proses membaca kritis agar tidak langsung mempercayai semua informasi yang didapat (Sharp, 2012).

Untuk meningkatkan kualitas literasi informasi, membaca kritis adalah sarana yang bisa membantu agar pembaca tidak mudah menyerap dan mempercayai infomasi yang sudah didapat. Menurut Albert dalam Tarigan (2008) membaca kritis yakni membaca yang dilakukan dengan bijaksana, penuh tenggang hati, mendalam, evaluatif, serta analisis, bukan hanya mencari kesalahan. Sedangkan menurut Rahardi (2010) membaca kritis merupakan kegiatan untuk mendapatkan informasi yang relevan dan diperlukan. Maka dari itu, membaca kritis adalah suatu kegiatan membaca yang dilakukan secara analisis dan menilai terhadap teks yang dibaca. Oleh karena itu membaca kritis haruslah menjadi proses yang mutlak untuk menggali informasi yang mendalam dalam proses membaca.

Untuk mempermudah proses membaca kritis dapat dilakukan melalui proses analisis wacana kritis. Analisis wacana kritis awalnya digunakan untuk menyelidiki secara kritis adanya ketidakseimbangan sosial yang diekspresikan dalam bentuk penggunaan bahasa wacana (Weiss dan Wodak, 2002). Analisis wacana kritis melihat teks sebagai tindak tutur. 
Dengan demikian, analisis wacana kritis berefek pada cara suatu bahasa digunakan dan cara sebuah makna dapat terbentuk. Sifat multidisipliner yang kini tersemat dalam analisis wacana kritis berimplikasi pada penggunaan analisis wacana kritis untuk beragam fungsi dalam teori dan metode penelitian.

Salah satu ahli analisis wacana kritis yaitu Norman Fairclough (1995) menyatakan bahwa pada semua teks terkandung ideologi. Ideologi tersebut tercermin dari pemakaian kosakata, kalimat, dan wacana tertentu. Bahasa tidak dimaknai sebagai sesuatu yang netral, tetapi terintegrasi dengan ideologi yang membawa muatan kekuasaan tertentu. Cara memahami ideologi dibalik sebuah representasi adalah mengkaji bahasa yang digunakan secara kritis. Persoalan hubungan bahasa dan kuasa selalu terikat erat dengan politik. Politik selalu berkaitan dengan penguasaan terhadap orang banyak. Alat yang efektif digunakan untuk penguasaan itu adalah bahasa. Dalam wacana politik akan terjadi dominasi simbolsimbol kebahasaan dari partisipan yang memiliki kuasa yang lebih tinggi atau lebih besar kepada partisipan yang dikuasai, atau terjadi subordinasi terhadap partisipan yang berada pada posisi rendah oleh partisipan pemegang kendali.

Di Indonesia kondisi politik saat ini seringkali menyita perhatian media terutama dalam hal pergantian pemimpin suatu wilayah. Pesta demokrasi kian diwarnai dengan pemberitaan mengenai pasangan calon atau disingkat paslon. Berbagai macam perubahan yang ditawarkan ketika paslon tersebut berhasil terpilih menjadi kepala daerah atau presiden dalam ajang pemilihan umum (Novenanto, 2010). Sebagai wacana, teks berita yang mengandung bias, menarik untuk dibedah dengan analisis wacana kritis. Analisis wacana kritis berpandangan menyampaikan informasi dalam teks media massa mengandung bias kepentingan (ideologi), baik kepentingan bisnis, politik, maupun kepentingan lain (Sultan, 2018). Kecenderungan ketidaknetralan pemberitaan di media massa itu disebabkan oleh frame atau bingkai yang digunakan oleh wartawan dan media (Muslich, 2008).

Konstruksi pemberitaan dari suatu media erat kaitannya dengan ideologi media dan penulis media (wartawan) tersebut, sehingga pemberitaan-pemberitaan yang disajikan oleh wartawan pun sangat dipengaruhi oleh pengetahuan, dan sudut pandangnya dalam merefleksikan suatu peristiwa ke dalam sebuah wacana yang bermakna. Pentingnya membaca kritis berita politik melalui analisis wacana kritis oleh siswa bertujuan untuk memberikan pendidikan politik sejak dini bagi siswa khususnya bagi pemilih pemula yang baru pertama kali memberikan suaranya dalam pemilihan umum. Tujuan pendidikan politik bagi peserta didik yakni agar peserta didik memiliki kemampuan berpikir secara kritis, rasional, dan kreatif dalam menanggapi isu kewarganegaraan, berpartisipasi secara aktif, dan bertanggung jawab dan bertindak secara cerdas dalam kegiatan bermasyarakat, berbangsa dan bernegara, anti-korupsi, serta membentuk diri berdasarkan karakter-karakter masyarakat Indonesia yang dapat hidup bersama dengan bangsa-bangsa lainnya (Mutia, 2016).

Sebelumnya telah dilakukan penelitian serupa mengenai analisis wacana kritis memanfaatkan media massa. Riset tersebut dilakukan oleh Jufri (2015) menunjukkan bahwa wacana iklan sarat dengan muatan ideologi dan kekuasaan. Ideologi dan kekuasaan dikonstruksi dan direkonstruksi oleh bahasa. Wujud linguistik yang didayagunakan terdiri atas kosakata, modalitas, angka, pronomina, frasa, klausa, dan kalimat. Penelitian lainnya 
dilakukan oleh Hasanah (2017) menunjukkan bahwa teks berita seratus hari pertama pemerintahan Jokowi-JK menampilkan Jokowi sebagai presiden yang dikendalikan oleh partai politik pendukung, dan presiden yang berani dan tegas. Secara tekstual ketiga media online tersebut merepresentasikan kepemimpinan Jokowi dengan menggunakan kosakata dan gramatikal yang berbeda antara satu dengan yang lainnya. Perbedaaan tersebut berimpilikasi pada pada perbedaan orientasi penggunaan bahasa oleh media online Detik.com, Kompas.com, dan Republika Online. Selanjutnya penelitian Kuntarto (2018) menunjukkan ada 4 kelompok dan 36 jenis gaya bahasa yang digunakan oleh para politikus dalam bertutur di media sosial daring, yaitu ironi (21 jenis), perbandingan ( 7 jenis), pertentangan (4 jenis), dan penegasan (4 jenis). Hasil juga diketahui 4 fenomena gaya bahasa politikus oposan di Indonesia, yaitu, 1) kecenderungan untuk menggunakan diksi yang bermakna sarkastik, melecehkan, membuli, menyudutkan, menyatakan yang sebaliknya, dan apriori; 2) kebenaran realistis dikalahkan oleh kebenaran praktis, 3) hilangnya sikap empati, penghargaan, dan kesantunan; 4) bahasa digunakan sebagai alat politik, dan bukan sebagai alat interaksi sebagaimana dimaksud dalam teori kesantunan berbahasa.

Ketiga penelitian sebelumnya telah membahas kajian analisis wacana kritis dengan perspektif Norman Fairclough untuk mengetahui ideologi dalam teks berita politik dalam program televisi, media iklan, media sosial, dan portal media online. Penelitian-penelitian tersebut oleh calon peneliti dianggap relevan. Berdasarkan penelitian-penelitian sebelumnya, diketahui bahwa belum ada yang pernal meneliti mengenai analisis wacana kritis berita politik sebagai bentuk pendidikan politik bagi siswa serta peranannya dalam pembelajaran membaca kritis di sekolah. Penelitian ini bertujuan untuk menyelidiki sisi lain dari bahasa kekuasaan dengan menggunakan analisis wacana kritis Norman Fairclough dengan harapan dapat mengungkap bahasa kekuasaan melalui fitur-fitur linguistik seperti, kosakata, gramatikal, dan struktur teks serta perannya dalam pembelajaran membaca kritis dan pendidikan politik bagi siswa. Dengan adanya penelitian ini diharapkan siswa sebagai pemilih pemula mendapatkan bekal pendidikan politik guna membantu menganalisis beritaberita politik yang menyebar di berbagai media massa.

\section{Metode Penelitian}

Penelitian ini menggunakan metode kualitatif linguistik kritis yang bersifat deskriptif dengan menggunakan pendekatan analisis wacana kritis Norman Fairclough. Data dalam penelitian ini berupa kata, frasa, klausa, kalimat yang menampilkan fitur bahasa kekuasaan dan perannya dalam pembelajaran literasi kritis. Data bersumber dari media daring Fajar.co.id pada berita pemilihan Walikota Makassar tahun 2020. Teknik pengumpulan data yang digunakan yaitu teknik dokumentasi, baca, dan pencatatan. Instrument penelitian yaitu peneliti sendiri yang berkedudukan sebagai perencana, pelaksana, pengumpul data, penganalisis data, penafsir data, dan menjadi pelapor hasil penelitin (Moleong, 2017). Teknik analisis data dalam penelitian ini, yaitu menggunakan model Miles, Huberman, dan Saldana (2014) melalui prosedur mengidentifikasi data, mengklasifikasi data, menganalisis data, dan menarik kesimpulan. 


\section{Hasil Penelitian dan Pembahasan}

Perubahan linguistik pada ilmu sosial membawa dampak pada penelitian di bidang pendidikan, tidak terkecuali analisis wacana kritis, yang dianggap sebagai salah satu bagian dari metodologi dan pendekatan studi bahasa dalam dunia pendidikan. Berdasarkan studi referensi yang dilakukan, analisis wacana kritis berperan setidaknya dalam tiga bidang pembelajaran, yakni pada peningkatan kemampuan berpikir kritis siswa, kemampuan literasi kritis siswa, serta kesadaran berbahasa kritis siswa (Sultan, 2018). Berikut akan disajikan analisis wacana mengenai fitur bahasa kekuasaan dalam teks berita pemilihan Walikota Makassar pada media daring Fajar.co.id dengan menggunakan analisis wacana kritis Norman Fairclough. Penelitian ini merupakan upaya untuk mengungkap ideologi yang terkandung dalam fitur bahasa kekuasaan pada fitur kosakata, fitur gramatika, dan fitur strukter teks dalam hal ini interpretasi fitur bahasa dalam kaitannya dengan pendidikan politik dan pembelajaran membaca kritis bagi siswa.

\section{Data Pada Fitur Kosakata dalam Teks Berita Pemilihan Walikota Makassar.}

\section{a) Evaluasi Positif dan Negatif}

Evaluasi positif dan negatif merujuk pada sejumlah kosakata yang mengekspresikan identitas subjek dan identitas sosial terhadap realitas. Data dalam penelitian ini yang berkaitan dengan hal tersebut sebagai berikut.

(D2 ${ }^{\mathbf{1}}$ ) Dia mengaku kenapa warga sebaiknya memilih pasangan DannyFatma (Adama), Pertama, hanya pasangan urut satu yang berpasangan dengan sosok perempuan tangguh. Kedua, Adama hanyalah anak Lorong yang tidak punya sekat dengan rakyat.

Pada data $\mathbf{D 2}{ }^{\mathbf{1}}$ terdapat fitur kosakata meliputi evaluasi positif pada kata perempuan tangguh dan anak lorong. Perempuan tangguh merupakan evaluasi positif yang diberikan kepadan sosok paslon ibu Fatma yang menjadi calon wakil walikota pasangan Danny Pamanto. Sosok perempuan tangguh memiliki makna ideologi tangguh secara emosional yang mampu memanagemen diri dan bertanggung jawab dengan segala usaha yang telah dilakukan. Sosk perempuan yang kuat, pekerja keras, serba bisa, dan dapat diandalkan, begitupun dengan anak lorong yang mengandung ideologi anak yang terlahir dari lingkungan rakyat, tidak mempunyai sekat atau batasan dengan warga lainnya. Sehingga jika paslon Danny-Fatma memenangkan pilwalkot Makassar dan akan menjadi pemimpin yang sangat mudah berbaur dengan masyarakat. Pemilihan kata perempuan tangguh dan anak lorong memiliki ideologi bahasa kekuasaan yang memiliki power atau kekuataan untuk mampu menguasai pemikiran pendukungnya. Bahasa kekuasaan yang ditampilkan pada paslon Danny-Fatma sebagai peranti kekuasaan yang tersembunyi dibalik fitur linguistik kosakata evaluasi postif untuk mereka yang memiliki niat berkuasa memenangkan pemilihan Walikota Makassar.

\section{b) Metafora}

Metafora sering digunakan untuk mengonkretkan konsep abstrak juga didayagunakan untuk menguat pesan ideologi. Data dalam penelitian ini yang berkaitan dengan hal tersebut sebagai berikut.

(D9 $\left.{ }^{1}\right)$ Mulai dari akar rumput sampai level elite. 
Pada data $\mathbf{D 9}^{\mathbf{1}}$ terdapat fitur kosakata meliputi metafora pada kata akar rumput. Fitur metafora yang digunakan untuk menampilkan hal yang konsepnya nyata dengan diibaratkan akar rumput yang bagian paling terbawah. Pengunaan kata akar rumput ini diibaratkan semua masyarakat dari kalangan yang terbawah sampai kalangan elit atau kalangan atas. Paslon Ical-Fadli dianggap bisa diterima dari semua kalangan masyarakat. Jenis metafora pada kata akar rumput yakni jenis antropomorfik yang mengacu pada benda yang tidak bernyawa dilakukan dengan mengalihkan atau memindahkan dari tubuh manusia. Kemudian, dialihkan untuk benda-benda yang sebenarnya tidak hidup atau tidak bernyawa dipahami sebagai hidup atau bernyawa. Bahasa kekuasaan yang ditampilkan pada paslon Ical-Fadli seabagai peranti kekuasaan yang tersembunyi dibalik fitur linguistik kosakata meliputi metafora untuk mereka yang memiliki niat berkuasa memenangkan pemilihan Walikota Makassar.

\section{c) Kata-Kata Formal dan Informal}

Kata-kata formal dan nonformal yakni sebuah kepemilikan yang lazim dalam banyak masyarakat, baik pada tataran praktik maupun wacana yang berkenaan dengan pratik sosial yang tinggi dan akses yang dalam sebuah relasi sosial. Kata formal ditunjukkan melalui kosakata asing dan kosakata ilmiah, sedangkan kata informal kosakata yang digunakan untuk tujuan menciptakan keakraban, kesantunan, solidaritas, dan ekspresi afektif dengan pendengar. Data dalam penelitian ini yang berkaitan dengan hal tersebut sebagai berikut.

(D12 $\left.{ }^{1}\right)$ Gerakan door to door yang dilakukan Rezki, Legislator Partai Demokrat dalam memenangkan Munafri Arifuddin-Rahman Bando (Appi-Rahman) di Pilwalkot Makassar diyakini dapat mendongkrak elektabilitas pasangan nomor urut 2 itu.

Pada data D12 ${ }^{1}$ terdapat fitur kosakata meliputi kata formal atau bahasa asing ditandai dengan kalimat Gerakan door to door yang dilakukan Rezki, Legislator Partai Demokrat dalam memenangkan Munafri Arifuddin-Rahman Bando (Appi-Rahman) di Pilwalkot Makassar. Fitur kosakata formal memberikan kesan wibawa sosial dan menciptakan kesankesan ekekuasaan posisi dan status elite politik. Ada ideologi dibalik penggunaan teks dengan kosakata bahasa asing door to door yang artinya mengunjungi rumah warga dari pintu ke pintu rumah warga lainnya dalam melaksanakan proses kampanye untuk menarik simpati warga dan diyakini dapat menaikkan elektabilitasnya paslon Appi-Rahman. Bahasa kekuasaan yang ditampilkan pada paslon Appy-Rahman sebagai peranti kekuasaan yang tersembunyi dibalik fitur linguistik kosakata meliputi metafora untuk mereka yang memiliki niat berkuasa memenangkan pemilihan Walikota Makassar.

\section{d) Relasi Makna Ideologis}

Relasi makna ideologis merupakan keberadaan kata-kata tertentu terkait hubugannya dengan relasi maknanya sering mempunyai makna ideologis. Relasi makna yang kerap kali mempunyai makna ideologis meliputi antonim, sinonimi, dan hiponimi.

$\left(\mathbf{D 1 5}^{\mathbf{1}}\right)$ Sebagai pemimpin yang punya berbagai inovasi, Danny akan membuat lorong wisata guna meningkatkan taraf hidup masyarakat utamanya di dalam lorong. "Insya Allah jika Adama diberi kesempatan memimpin Makassar lima tahun kedepan. Saya akan kembali membangkitkan program lorong wisata supaya ibu-ibu 
bisa usaha kecil-kecilan di lorong, Yah bisa jual kue atau kerajinan tangan" pungkasnya.

Pada data $\mathbf{D 1 5}{ }^{1}$ terdapat fitur kosakata meliputi relasi makna ideologis sinonim pada kata meningkatkan dan membangkitkan. Adanya padanan makna yang memiliki hubungan antara bentuk bahasa yang mengandung ideologi untuk memberikan kredibilitas paslon Danny-Fatma untuk mendapatkan simpati masyarakat dengan berbagai program yang diberikan, salah satunya program lorong wisata. Bahasa kekuasaan yang ditampilkan pada paslon Danny-Fatma sebagai peranti kekuasaan yang tersembunyi dibalik fitur linguistik kosakata meliputi relasi makna ayng ideologis untuk mereka yang memiliki niat berkuasa memenangkan pemilihan Walikota Makassar. Nilai formal yang terkandung dalam teks ini ialah nilai pengalaman atau experiential sebagai sebuah tanda atau isyarat pengalaman dari paslon yang berhubungan dengan isi, pengetahuan, dan ideologi sang penghasil teks. Nilai pengalaman berisi tentang gambaran peristiwa, orang, kelompok, situasi, keadaan, atau apa pun yang ditampilkan ke dalam teks.

\section{e) Eufimistik}

Eufimistik merupakan eksprsi kebahasaan yang bertujuan untuk memperhalus realitas yang sebenarnya. Data dalam penelitian ini yang berkaitan dengan hal tersebut sebagai berikut.

(D17) "Majelis taklim salah satu garda utama. Madrasah pertama untuk anak-anak. Saya 10 tahun sebagai pembina majelis taklim paham keluhan ta semua. Saya tidak ingin memberi janji, tapi insyaAllah hanya perempuan yang mengerti perempuan," ucap Fatmawati.

Pada data $\mathbf{D 1 7}^{\mathbf{1}}$ terdapat fitur eufimistik pada kalimat hanya perempuan yang mengerti perempuan. Eufimistik yang merupakan ekpresi kebahasaan yang bertujuan memperhalus realitas sebenarnya. Ideologi yang ditanamkan ibu Fatmawati kepada ibu-ibu majelis taklim yang berpihak kepada ibu-ibu mewakili perempuan untuk memperjuangan hak perempuan. Tentunya ini sangat menarik perhatian ibu-ibu yang merasa ada kepedulian terhadap sesama perempuan. Dibandingkan paslon yang lain, hanya paslon Danny-Fatma yang memiliki pasangan wakil perempuan. Pendekatan terhadap ibu-ibu majelis taklim memiliki ideologi kekuasaan terhadap pemilihan bahasa dengan menandakan hanya perempuan yang mengerti perempuan. Bahasa kekuasaan yang ditampilkan pada paslon Danny-Fatma sebagai peranti kekuasaan yang tersembunyi dibalik fitur linguistik kosakata meliputi ekspresi eufimistik untuk mereka yang memiliki niat berkuasa memenangkan pemilihan Walikota Makassar.

\section{Data Pada Fitur Gramatika dalam Teks Berita Pemilihan Walikota Makassar.}

\section{a) Pemasifan}

Pemasifan merupakan proses tindakan dapat muncul dalam kalimat aktif maupun pasif. Penghasil teks mungkin saja menggunakan kalimat pasif tanpa agen membiarkan kausalita dan ketidakjelasan agen (Fairclough). Data dalam penelitian ini yang berkaitan dengan hal tersebut sebagai berikut. 
(D19) Selama ini walikota Makasaar 2013-2018 Danny Pomanto yang berpasangan dengan wakil walikota Syamsu Rizal banyak dikritik karena berbagai macam program yang terbengkalai. Misalnya Tempat Pembuangan Akhir (TPA) sampah bintang lima, tempat sampah gendang dua, pete-pete smart, halte kapsul, apartemen lorong dan sebagainya. Bahkan rumah sakit Batua sampai sekarang mangkrak.

Pada data $\mathbf{D 1 9}{ }^{2}$ terdapat fitur gramatika meliputi pemasifan atau kalimat pasif pada kata dikritik. Bentuka kata dasar "kritik" menjadi "dikritik" karena mendapat afiks "di-“. Kata dikritik mengalami efek kalimat pasif, sehingga aktor yang mengkritik dihilangkan. Aktor yang mengkritik itu bisa saja masyarakat, pejabat, atau kalangan tertentu yang tidak ditampilkan. Penghilangan aktor tersebut bersembuyi dibalik kalimat pasif yang ada pada teks. Pembahasan kalimat pasif didasarkan atas sifat hubungan atau relasi dalam subjek dengan predikat dalam kalimat. Apabila kalimat ini aktif akan menampilkan aktornya seperti, Masyarakat mengkritik Walikota Makassar 2013-2018 Danny Pamanto yang berpasangan dengan wakil walikota Syamsu Rizal karena berbagai program yang terbengkalai. Bahasa kekuasaan yang ditampilkan pada paslon Appy-Rahman sebagai peranti kekuasaan yang tersembunyi dibalik fitur linguistik gramatika meliputi pemasifan untuk mereka yang memiliki niat berkuasa memenangkan pemilihan Walikota Makassar.

\section{b) Ketransitifan}

Ketransitifan membahas mengenai unsur-unsur gramtikal yang dipakai secara sistematis untuk mengungkapkan hubungan-hubungan antara partisipan yang terlibat dalam situasi komunikasi, perbuatan, keadaan, atau peristiwa. Data dalam penelitian ini yang berkaitan dengan hal tersebut sebagai berikut.

$\left(\mathbf{D 2 0}^{2}\right)$ Appi sapaan Munafri Arifuddin terlihat turun langsung ke jalan sekitar

Karebosi membagikan masker kepada pengguna jalan.

Pada data $\mathbf{D 2 0}^{2}$ terdapat fitur gramatika meliputi ketransitifan pada kata membagikan masker. Ketransitifan dikaitkan dengan pemahaman kita terhadap realitas apa yang sedang berlangsung. Makna sebuah predikat dan nomina yang terkait dengan predikat tesebut. Kata membagikan merupakan bentuk verba dan masker merupakan bentuk nomina yang menggambarkan tindakan atau action yang dipakai untuk mengungkapkan hubungan antara partisipan yang terlibat dalam situasi membagikan masker sebagai bentuk kepedulian terhadap situasi pandemi covid-19 saat ini. Ada ideologi dibalik tindakan membagikan masker untuk menarik simpati masyarakat terhadap apslon Appi-Rahman. Bahasa kekuasaan yang ditampilkan pada paslon Appy-Rahman sebagai peranti kekuasaan yang tersembunyi dibalik fitur linguistik gramatika meliputi ketransitifan untuk mereka yang memiliki niat berkuasa memenangkan pemilihan Walikota Makassar.

\section{c) Modalitas}

Modalitas ialah klasifikasi proposisi menurut hal mengingkari kemungkinan atau keharusan, juga cara pembcara menyatakan sikap terhadap suatu situasi dalam komunikasi antarpribadi. Data dalam penelitian ini yang berkaitan dengan hal tersebut sebagai berikut.

$\left(\mathbf{D 2 1}^{2}\right)$ Menurut Anton, memenangkan Dilan adalah kewajiban bagi seluruh kader dan legislator dari Fraksi PDIP. "Sudah jadi perintah partai untuk memenangkan 
Dilan, beberapa daerah yang menjadi basis kemenangan saya di Pileg kemarin akan kita utamakan," lanjutnya.

Pada data D21 ${ }^{2}$ terdapat fitur gramatika meliputi modalitas deontik pada kata perintah. Perintah yang diungkapkan dengan pengunaan kewajiban bagi selurih kader dan legislator dari Fraksi PDIP sudah menjadi perintah untuk memenangkan paslon Daeng IchalFadli yang dikenal dengan sapaan Dilan. Modalitas denotik berhubungan dengan kewajiban atas dasar kewenangan pribadi atau kewenangan resmi yang memerintah, sehingga ada wujud kekuasaan dalam memerintah seluruh kadernya untuk memilih dan memenangkan paslon Dilan dalam pemilihan Walikota Makassar. Bahasa kekuasaan yang ditampilkan pada paslon Ical-Fadly sebagai peranti kekuasaan yang tersembunyi dibalik fitur linguistik gramatika meliputi modalitas denotik untuk mereka yang memiliki niat berkuasa memenangkan pemilihan Walikota Makassar.

\section{d) Modus Kalimat}

Modus kalimat berkenaan dengan cara bagaimana kalimat itu diekspresikan kepada mitra bicara. Terdapat tiga macam modus kalimat, yaitu deklaratif, interogratif, dan imperatif. Data dalam penelitian ini yang berkaitan dengan hal tersebut sebagai berikut.

$\left(\mathbf{D 2 5}^{2}\right)$ Olehnya Appi-Rahman melakukan aksi nyata dengan membagikan 4 juta lembar masker dan 500 handsanitizer kepada seluruh warga Makassar tanpa terkecuali.

Pada data $\mathbf{D 2 5}^{2}$ terdapat fitur gramatika meliputi modus kalimat deklaratif. Posisi penutur sebagai pemberi informasi mengenai pembagian 4 juta masker dan 500 handsanitizer kepada warga kota Makassar sebagai bentuk kepedulian paslon Appi-Rahman terhadap situasi pandemi covid-19. Adanya wujud aksi nyata yang dilakukan memberikan manfaat yang dapat dirasakan oleh masyarakat melalui pembagian masker dan handsanitizer. Tentunya masyarakat akan memberikan simpati pada paslon Appi-Rahman yang peduli akan kesehatan warga kota Makassar. Bahasa kekuasaan yang ditampilkan pada paslon AppyRahman sebagai peranti kekuasaan yang tersembunyi dibalik fitur linguistic gramatika meliputi modus kalimat deklaratif untuk mereka yang memiliki niat berkuasa memenangkan pemilihan Walikota Makassar.

\section{e) Nominalisasi}

Nominalisasi ialah sebuah proses gramatikal dalam pembentukan nomina dari jenis kata lain, yang biasanya berasal dari verba atau adjektif. Dalam kaitannya dengan analisis wacana kritis, pilihan terhadap nominalisasti tertentu pada sebuah teks mengandung signifikansi atau makna ideologis tertentu. Proses nominalisasi melihat bagaimana penghasil teks mengolah posisi agen-agen tertentu dengan menggunakan proses nominalisasi tertentu.

$\left(\right.$ D26 $\left.^{1}\right)$ "Pak Appi ini sosok tenang dan bisa berpikir jernih, terlihat dari sikapnya menanggapi kasus penikaman itu Pak Appi langsung menyerukan tidak boleh ada balas dendam. Makassar ini butuh pemimpin kayak Pak Appi yang tidak emosional,"terangnya.

Pada data $\mathbf{D 2 6}{ }^{1}$ terdapat fitur gramatika meliputi nominalisasi pada kata penikaman. Pada kalimat ini terjadi rekayasa lingual dengan nominalisasi yakni perubahan verba "menikam" menjadi nomina "penikaman" nominalisasi membuat agen pelaku menjadi tidak 
dibutuhkan lagi dalam kalimat. Sehingga pembaca hanya berfokus pada kasusnya tanpa mengetahui siapa agen atau pelaku dari kasus penikaman tersebut. Nominalisasi ditandai dengan penggunaan kata benda (nomina) yang menghilangkan aktor sosial di dalam teks dengan imbuhan pe- dan -an, sehingga bermakna peristiwa. Bahasa kekuasaan yang ditampilkan pada paslon Appy-Rahman sebagai peranti kekuasaan yang tersembunyi dibalik fitur linguistik garamatika meliputi nominalisasi untuk mereka yang memiliki niat berkuasa memenangkan pemilihan Walikota Makassar.

\section{Data Pada Fitur Struktur Teks Dalam Teks Berita Pemilihan Walikota Makassar}

\section{a) Implikatur}

Implikatur merupakan sebuah tindak yang dilakukan dengan tujuan atau maksud tertentu, penuturlah yang menyampaikan makna lewat implikatur dan pendengarlah yang mengenali makna yang disampiakan lewat inferensi tersebut. Melalui sebuah implikatur, seorang penutur memaksakan ideologinya kepada orang lain. Data dalam penelitian ini yang berkaitan dengan hal tersebut sebagai berikut.

$\left(\mathbf{D 2 7}^{3}\right)$ Danny menambahkan bahwa satu bukti lebih baik daripada seribu janji.

Olehnya, kata dia pasangan Adama memiliki komitmen serius dan tidak suka menjanji.

Pada data $\mathbf{D 2 7} \mathbf{3}^{\mathbf{3}}$ terdapat fitur struktur teks meliputi implikatur. Posisi penutrlah yang menyampaikan makna lewat implikatur dan pendengarlah yang mengenali makna yang disampaikan lewat inferensi tersebut. Paslon Danny-Fatma memberikan pernyataan bahwa satu bukti lebih baik daripada seribu janji. Olehnya, kata dia pasangan Adama memiliki komitmen serius dan tidak suka menjanji”. Struktur teks yang digunakan aktor politik menggunakan bahasa dalam bentuk slogan dengan cara menyindir lawan politiknya untuk memengaruhi masyarakat. Ideologi yang diberikan begitu mendalam kepada masyrakat, dalam artian bentuk teks mikro yang memiliki kekuatan konteks makro dalam hal ini masyarakat luas Makassar. Satu bukti lebih baik daripada seribu janji memberikan pandangan jejak politik Danny Pamanto yang sebelumnya telah menjabat walikota Makassar. Memberikan bukti nyata melalui program kerja yang dibuat dan dirasakan hasilnya, oelh warga kota Makassar membuat paslon ini yang menjadi penutur yang menyampaikan makna lewat implikatur dengan maksud terntentu dan pendengar atau pembaca mengenali manamakna yang disampaikan lewat inferensi tersebut. Hal tersebut membawa muatan idelogi bahasa kekuasaan yang dapat memengaruhi masyarakat untuk lebih melihat paslon yang telah memberi bukti sebelumnya, daripada paslon yang hanya memberikan seribu janji. Inilah menjadi fitur struktur teks bahasa kekuasaan implikatur.

\section{b) Gilir Tutur}

Gilir tutur menunujukkan bahwa sebuah percakapan bukanlah sesuatu yang bebas aturan, tetapi terdapat aturan yang bebas untuk kontribusi peserta dan gili tuturnya. Data dalam penelitian ini yang berkaitan dengan hal tersebut sebagai berikut.

(D28) "Sebagai ketua DPD PDIP Sulsel, kita akan kerja mati-matian memenangkan Dilan. Jangan pernah ragukan PDIP tidak all out. Jika ada kader tidak mendukung Dilan, saya tidak segan pecat. Jangankan tidak menusuk, posting 
paslon lain saja di sosmed, akan saya pecat," tegas Ridwan Wittiri dalam orasinya di gelaran Deklarasi pasangan Deng Ical-Fadli di Tribun Lapangan Karebosi.

Pada data $\mathbf{D 2 8}{ }^{2}$ terdapat fitur struktur teks meliputi gili tutur ditandai dengan tuturan ketua DPD PDIP Sulsel yang sistem gili tuturnya berhubungan dengan kekuasaan antarpartisipan dalam memeroleh informasi. Adanya aktor yang berkuasa dan yang dikuasai adalah kader PDIP jika tidak mendukung Dilan, tidak segan pecat. Jangankan tidak menusuk, posting paslon lain saja di sosmed, akan saya pecat," tegas Ridwan Wittiri dalam orasinya di gelaran Deklarasi pasangan Deng Ical-Fadli di Tribun Lapangan Karebosi. Adanya kekuasaan dalam mengendalikan pilihan anggota kader partai partai dalam mendukung paslon no. urut 3 yaitu Ical-Fadli. Tuturan yang bersifat mengancam mengikat penuturnya untuk melaksanakan apa yang disampaikan dalam tuturannya.

\section{c) Sapaan, Nama, dan Rujukan Pribadi}

$\left(\right.$ D29 $\left.^{3}\right)$ Pemilihannya tahun lalu akan terus $i a$ akomodir untuk memilih paslon bejargon Makassar Bangkit pada 9 Desember mendatang. Ia optimis dan percaya, konsituenya berada dalam satu komando bergerak door to door memenangkan Appi-Rahman.

Pada data $\mathbf{D 2 9}^{3}$ terdapat fitur struktur teks meliputi sapaan, nama, dan rujukan pribadi. Kata $i a$ a tau dia menunjukkan pronominal persona kedua yang menginformasikan banyak hal tentang kuasa dan solidarita. Kecenderungan pewawancara seing menyapa yang diwawancarai sengan sebutan "anda" dan jarang sekali menggunakan sebutan "Bapak," maka kita dapat memeroleh pemahaman bahwa relasi solidaritas yang dominan dalam interaksi kebahasaan itu. Terdapat nilai formal ialah nilai relasional yang menunjukkan sebuah tanda atau isyarat hubungan sosial yang diwakili oleh teks pada wacana. Dengan kata lain, nilai relasional berkenaan dengan interaksi dan hubungan sosial yang digambarkan dalam teks. Pada pilihan proses penyusumam sebuah teks bergantung dan membantu menciptakan hubungan sosial antar partisipan. Konstruksi hubungan ini dalam teks sangat penting dan signifikan terutama kalau berhubungan dengan konteks sosial karena pengaruh unik dari posisi-posisi mereka yang ditampilkan dalam media menunjukkan konteks masyarakat.

\section{d) Pengontrolan Partisipan}

Pengontrolan partisipan berhubungan bagaimana car-cara seoorang participant mengontrol kontribusi pastisipan lainnya. Data dalam penelitian ini yang berkaitan dengan hal tersebut sebagai berikut.

$\left(\mathbf{D 3 0}^{3}\right)$ "Insya Allah jika Adama diberi kesempatan memimpin Makassar lima tahun kedepan, Saya akan kembali membangkitkan program lorong wisata supaya ibuibu bisa usaha kecil-kecilan di lorong, Yah bisa jual kue atau kerajinan tangan."pungkasnya.

Pada data $\mathbf{D 3 0}^{3}$ terdapat fitur struktur teks meliputi pengontrolan partisipan yang memiliki kekuasaan besar akan memaksakan kontribusinya kepada partisipan lainnya. Partisipan yang memiliki kekuasaan dalam hal ini lalah paslon Danny-Fatma dan partisipan lainnya dalam hal ini ialah ibu-ibu yang hadir pada kampanye Adama. Formulasi terjadi jika seorang penutur meminta mitra tutur untuk merumuskan kembali apa yang sudah dikatakan. Formulasi ini memiliki tujuan untuk mengontrol pemahaman dan membatasi pilihan 
partisipan untuk kontribusinya. Hal inilah yang akan memasukkan ideologinya kepada partisipan lainnya, yakni paslon Adama melakukan kontrol partisipan ibu-ibu yang menghadiri kampanye tersebut.

\section{Peran Analisis Wacana Kritis dalam Pembelajaran Membaca Kritis}

Pembelajaran membaca merupakan serangkaian aktivitas yang dilakukan sebelum memulai membaca sampai pada konstruksi makna teks setelah proses membaca berlangsung (Sultan, 2018). Pembelajaran membaca kritis dapat diorganisasikan dalam tahapan pembelajaran membaca secara umum di sekolah dalam pembelajara Bahasa dan Sastra Indonesia. Dalam situasi akademik dan kehidupan sehari-hari, peserta didik senantiasa berhadapan dengan berbagai jenis teks, seperti buku teks, koran, majalah, laporan ilmiah, dan media social. Pemahaman yang baik terhadap beragam jenis teks dibutuhkan peserta didik untuk memanfaatkan beragam tugas-tugas akademik. Teks media massa yang memiliki karakteristik tersendiri dapat dimanfaatkan sebagai sumber bahan ajar untuk mengembangkan keterampilan membaca peserta didik.

Teks-teks media massa yang memiiki beragam bentuk teks merupakan media yang tepat untuk melatih keterampilan membaca kritis terutama bagi siswa sehingga teks-teks tersebut dapat digunakan dalam pembelajaran membaca kritis di sekolah. Teks-teks dalam bentuk berita, editorial, opini, dan iklan seringkali dilandasi dominasi, propaganda, dan persuasi untuk memengaruhi persepsi masyarakat. Begitupula dengan pemilihan informasi oleh penulis, teks seringkali didasarkan adanya kepentingan tertentu, seperti kepentingan politik, kepentingan bisnis, kepentingan ideologi, atau kepentingan pemilik modal/pemilik media (Nurhadi, 2010). Dengan demikian, mengkaji teks-teks tersebut dengan pendekatan analisis wacana kritis akan mengembangkan sikap kritis siswa dalam menyikapi berbagai teks.

Sebagai bagian dari pendidikan politik bagi siswa di sekolah, proses membaca kritis berita politik melalui analisis wacana kritis, siswa dilatih untuk berpikir kritis melalui pemilihan bacaan-bacaan yang dapat memberikan pengetahuan mengenai makna tersirat dan makna tersurat dalam teks berita politik yang ada di berbagai media massa yang sarat dengan berbagai kepentingan pribadi maupun kelompok. Membaca kritis dapat melatih siswa untuk berpikir kritis untuk mengevaluasi apakah ide-ide atau informasi dalam berbagai berita tersebut biss diterima atau dipercaya. Selain itu, dengan memiliki keterampilan membaca kritis dan berpikir kritis maka siswa akan secara cepat mengambil keputusan di saat-saat krisis (Restuningsih, Dantes dan Sudiana, 2017).

\section{Kesimpulan}

Kesimpulan yang diperoleh dari penelitian ini yaitu fitur bahasa kekuasaan sebagai peranti kekuasaan melalui fitur lingusitik kosakata, fitur garamtika, dan fitur struktur teks pada teks berita Pemilihan Walikota Makassar pada media daring Fajar.co.id yang didayagunakan untuk mengonstruksi, mengontrol, dan menanamkan ideologi atau gagasan yang dituangkan dalam teks. Hal tersebut tampak dalam upaya penggambaran citra pasangan calon, penyampaian visi dan program, serta aktivitas kampanye dan kunjungan para calon. Melalui identifikasi tersebut, tampak bahwa masing-masing paslon melakukan praktik kekuasaannya 
dalam menyajikan teks ke pembaca. Melalui analisis wacana kritis berita politik, dapat meningkatkan kemampuan membaca kritis peserta didik dalam menyikapi berbagai teks-teks yang ada di media massa sebagai bentuk pendidikan politik.

\section{Saran}

Saran yang dapat disampaikan berdasarkan temuan penelitian ini adalah: (1) Bagi guru, dapat dimanfaatkan sebagai media yang digunakan untuk meningkatkan kemampuan membaca kritis peserta didik dengan menggunakan model analisis wacana kritis. (2) Bagi peserta didik, penelitian ini dapat dimanfaatkan sebagai gambaran analisis berita politik menggunakan model analisis wacana kritis untuk meningkatkan kemampuan membaca kritis peserta didik. (3) Penelitian ini juga dapat dimanfaatkan untuk peneliti selanjutnya dalam mencari peluang kajian lebih lanjut mengenai berita politik serta kajian analisis wacana kritis dan perannya terhadap pembelajaran membaca kritis.

\section{Daftar Pustaka}

Ahuja, P. \& G. C. Ahuja. (2010). How to Read Effectively and Efficiently. Diterjemahkan oleh Tina Martiani. Bandung: Penerbit Kiblat.

Cervetti, G., M.J. Pardales, \& J.S. Damico. (2001). A Tale of Differences: Comparing the Traditional, Perspectives, and Educational Goals of Critical Reading and Critical Literacy. Reading Online, http://www.readingonline.org/articles/Cervetti.

Fairclough, N. (1989). Language and Power. Relasi Bahasa, Kekuasaan, dan Ideologi. Malang: Boyan Pubhlishing.

Fairclough, N. (1992). Kesadaran Bahasa Kritis: Bagian Pendahuluan. Terjemahan-an oleh Hartoyo. 1995. Dalam Norman Fairclough (Ed.), Kesadaran Bahasa Kritis (hlm. 134). Semarang: IKIP Semarang Press.

Fairclough, N. (1995). Critical Discourse Analysis: The Critical Study of Language. New York: Logman Group Limited.

Hasanah, A. (2017). Konstruksi Realitas Seratus Hari Pertama Pemerintahan Jokowi-Jusuf Kalla di Media Online: Analisis Wacana Kritis Model Norman Fairclough. 11. Semarang.

Jufri. (2017). Wacana Kritis. Makassar: Badan Penerbit UNM.

Kuntarto, E. (2018). Bahasa Dan Kekuasaan Politik Oposan Di Indonesia: Analisis Wacana Kritis. Jurnal Kiprah, 6(2), 37-47. https://doi.org/10.31629/kiprah.v6i2.860

Miles, M.B., Huberman, A.M., \& Saldana, J. (2014). Qualitative Data Analysis a Method Sourcebook (3 ed.). Arizona: SAGE Publication

Moleong, J. Lexy. (2017). Metodologi Penelitian Kualitatif Edisi Revisi. Bandung: Rosda Karya.

Muslich, M. (2008). Kekuasaan Media Massa Mengonstruksi Realitas. Jurnal Bahasa dan Seni, 36(2): 150-159.

Mutia, Rayi. (2016). Peran Sekolah dalam Pendidikan Politik Bagi Siswa di Sekolah Menengah Atas Islam Hidayatullah Semarang. Semarang: Universitas Diponegoro.

Novenanto, A. (2010). Melihat Kasus Lapindo sebagai Bencana Sosial. Jurnal Media Masyarakat, Kebudayaan, dan Politik, 23(1): 63-75.

Nurhadi. (2010). Teknik Membaca. Malang: Penerbit A3.

Priyatni, Endah Tri dan Nurhadi. (2017). Membaca Kritis dan Membaca Literasi Kritis. Tangerang: Tira Smart. 
Rahardi, Kunjana. (2010). Bahasa Indonesia Untuk Perguruan Tinggi. Jakarta: Erlangga.

Restuningsih, Anita, Dantes, N, Sudiana, N. (2017). Kemampuan Membaca Kritis Ditinjau dari Kemampuan Berpikir Kritis dan Minat Membaca Pada Siswa Kelas V SD Kristen Harapan Denpasar. Jurnal Pendidikan Dasar Indonesia, 1(1), 45-54.

Sharp, K. (2012). Breaking Down the Barries: Using Critical Literacy to Improve Educational Outcomes for Students in 21st-century Australian Classroom. Literacy Learning, 20(1):9-15.

Sultan. (2018). Membaca Kritis: Mengungkap Ideologi Teks dengan Pendekatan Literasi Kritis. Yogyakarta: Baskara Media.

Tarigan, H.G. (2008). Membaca sebagai Suatu Keterampilan Berbahasa (Edisi Revisi). Bandung: Penerbit Angkasa.

Weiss, Gilbert dan Ruth Wodak (Eds). (2002). Critical Discourse Analysis: Theory and Interdisciplinarity. New York: Palgrave Macmillan. 